\title{
Emerging viral threats in Gabon: health capacities and response to the risk of emerging zoonotic diseases in Central Africa
}

\author{
M Bourgarel $^{1,2}$, N Wauquier ${ }^{3}$ and J-P Gonzalez ${ }^{2}$ \\ ${ }^{1}$ Centre de Coopération Internationale en Recherche Agronomique pour le Développement (CIRAD), UPR AGIRs, Campus International de \\ Baillarguet, Montpellier cedex 5, France; ${ }^{2}$ Centre International de Recherches Médicales de Franceville (CIRMF), Unité de Recherche Ecologie de \\ la Santé, Franceville, Gabon; and ${ }^{3}$ Centre International de Recherches Médicales de Franceville (CIRMF), Unité des Maladies Virales \\ émergentes, Franceville, Gabon
}

\section{Correspondence}

Dr M Bourgarel, Unité Ecologie de la Santé, Centre International de Recherches Médicales de

Franceville (CIRMF), BP 2105 Libreville, Gabon.

E-mail: bourgarel@cirad.fr;

Web: http://www.cirmf.org

Received 11 March 2010

Accepted 3 June 2010
Emerging infectious diseases (EID) are currently the major threat to public health worldwide and most EID events have involved zoonotic infectious agents. Central Africa in general and Gabon in particular are privileged areas for the emergence of zoonotic EIDs. Indeed, human incursions in Gabonese forests for exploitation purposes lead to intensified contacts between humans and wildlife thus generating an increased risk of emergence of zoonotic diseases. In Gabon, 51 endemic or potential endemic viral infectious diseases have been reported. Among them, 22 are of zoonotic origin and involve 12 families of viruses. The most notorious are dengue, yellow fever, ebola, marburg, Rift Valley fever and chikungunya viruses. Potential EID due to wildlife in Gabon are thereby plentiful and need to be inventoried. The Gabonese Public Health system covers geographically most of the country allowing a good access to sanitary information and efficient monitoring of emerging diseases. However, access to treatment and prevention is better in urban areas where medical structures are more developed and financial means are concentrated even though the population is equally distributed between urban and rural areas. In spite of this, Gabon could be a good field for investigating the emergence or re-emergence of zoonotic EID. Indeed Gabonese health research structures such as CIRMF, advantageously located, offer high quality researchers and facilities that study pathogens and wildlife ecology, aiming toward a better understanding of the contact and transmission mechanisms of new pathogens from wildlife to human, the emergence of zoonotic EID and the breaking of species barriers by pathogens.

\section{Introduction}

Despite intensive research and considerable effort from public health agencies to prevent or eradicate infectious diseases, emerging infectious diseases (EID) are currently the major threat to public health worldwide. ${ }^{1}$ Indeed, many new infectious agents, characterized by a high pathogenic potential, have been recently identified. Furthermore, some well known pathogens have been expanding their territories, causing increasing concerns in the recent decades due to changing epidemiological patterns. ${ }^{2}$ Most of these EID events have involved zoonotic infectious agents: more than $60 \%$ of EID affecting humans have a zoonotic origin ${ }^{3,4}$ and $\sim 75 \%$ of the diseases that have emerged over the past two decades have wildlife sources. ${ }^{5}$ Therefore, zoonotic EID represent a major and increasing threat to global health. ${ }^{1,3,6}$
Zoonoses refer to infectious diseases that are susceptible to be transmitted from animals to humans and are responsible worldwide for a great deal of pain, morbidity and even human fatalities. Two categories of zoonotic diseases have been described: ${ }^{4}$ (1) diseases for which transmission events to humans are rare but once occurred, horizontal transmission from human-to-human maintains a more or less sustainable infectious cycle (for example: ebola virus, from naturally infected chiropteran to human epidemics); (2) diseases for which direct or vector-mediated animal-tohuman transmission remains the common source of human infection (for example: Rift Valley fever virus (RVFV), mosquito-transmitted from infected domestic ungulates).

Emerging and re-emerging zoonoses include recently identified infectious diseases, diseases that have recently

OPEn This is an Open Access article distributed under the terms of the Creative Commons Attribution licence (http://creativecommons.org/licenses/by/2.5) OPEN - ACCESS which permits unrestricted use, distribution, and reproduction in any medium, provided the original work is properly cited. 
evolved from a subclinical state to a clinical syndrome, and previously known diseases that have recently displayed an increase in incidence or that have spread to new regions, hosts or vectors. ${ }^{4}$ However, a disease may not be recognized as zoonotic at the first outset. The disease can spread undetected for a period of time depending on the incubation period (weeks to years), the epidemiological pattern of a subclinical disease to a clinical picture (the emergence of the symptoms depending on host or pathogen factors) or, if the number of cases, in both human and animal populations, is too small and undetectable during the initial stages of transmission to suspect a link between the two events. ${ }^{7}$

Zoonotic EID outbreaks result from a now classically accepted phenomenon of concurrency of fundamentals and territories of emergence. Fundamentals include factors related to the host, the vector (if any), the pathogen, and favorable environmental factors (climate) although territories at risk are the product of human activity and high-risk behavior among the human population. For instance, territories (that is: city, district) with an inefficient disease detection system or a failure to control vectors and other carriers of diseases as well as man-made environmental changes (breakdown of the water system, deforestation...) will force an increase in contact between the human population and wildlife. ${ }^{2,8}$

Tropical forests form the ecosystem harboring the highest species richness of all terrestrial ecosystems and shelter almost $50 \%$ of the total global biodiversity. ${ }^{9,10}$ This includes wildlife, flora, multi-cellular organisms as well as an immense diversity of pathogens including bacteria, parasites and viruses. Actually, there is a latitudinal spatial gradient of pathogenic species richness increasing towards the Equator. ${ }^{11}$ After the Amazonian Basin, the Congo basin in Central Africa has the world's second largest contiguous block of tropical rainforest, which encompasses many areas that remain largely undisturbed, due in large part to low human population densities and the remoteness of interior rainforests. ${ }^{12}$ As wildlife host species richness is a good predictor for the emergence of zoonotic EIDs with a wildlife origin, ${ }^{3}$ Central Africa in general, and Gabon in particular are privileged areas for the emergence of zoonotic EIDs.

\section{The potentialities of emerging zoonotic diseases from wild to domestic environments}

Latest reviews on EID show that nearly $75 \%$ of zoonotic EID have a wildlife origin. ${ }^{3,5,13-15}$ In fact, the number of EID events caused by pathogens coming from wildlife has increased during the past six decades. ${ }^{3}$ The majority of pathogens recorded were of viral origin. ${ }^{16}$ Therefore viral zoonoses of wildlife origin represent the most significant and growing threat to global health among all EIDs. ${ }^{3,13}$

As anthropogenic activities have been identified as the cause of a significant majority of outbreaks, ${ }^{16,17}$ it is essential to fully understand the mechanisms driving contacts between wildlife and the human population as well as speciesjumping infections to set up public health information campaigns. On the contrary, efforts to conserve areas rich in wildlife diversity (13 National Parks were created in 2002 in Gabon) by reducing anthropogenic activity may have an added value in reducing the likelihood of future zoonotic disease emergence in these areas. ${ }^{3}$ EIDs in free-living wild animals can be classified into three major groups on the basis of key epizootiological criteria: ${ }^{18}$ (i) EIDs associated with 'spill-over' from domestic animals to wildlife populations living in proximity; (ii) EIDs related directly to human intervention, via host or parasite translocations; and (iii) EIDs with no overt human or domestic animal involvement. These phenomena have two major biological implications: first, many wildlife species are reservoirs of pathogens that threaten domestic animal and human health; second, wildlife EIDs pose a substantial threat to the conservation of global biodiversity, with for example the disappearance of the most great ape populations in protected areas in Central Africa after the 2002-2003 ebola virus outbreaks. ${ }^{19-22}$

\section{Emerging zoonotic diseases in Gabon}

In Gabon, rainforests cover $\sim 80 \%$ of the territory. ${ }^{23}$ These forests are known for their rich biodiversity of animal and plant species. ${ }^{23}$ The human population, estimated at 1.5 million, ${ }^{24}$ lives more in cities (54\%) than in rural areas. ${ }^{25}$ Gabon's economy has relied in the past mainly on petroleum exports, forest exploitation, and mining activities. Forest habitats are now exploited by logging and mining companies, tourism and hunting activities, which produce about 17,500 metric tons per year of game meat. Altogether these human incursions in Gabonese forests for exploitation purposes lead to intensified contacts between humans and wildlife and generate a risk of emergence of zoonotic diseases. $^{26}$ This risk is not strictly restricted to the forest but exists countrywide as the urban demand for bush-meat in Gabon is important ( $>5 \mathrm{~kg} /$ per $/$ year $^{27}$ ). Indeed, every Gabonese city has traditional and local food markets where fresh and smoked bush-meat coming from all around the country are available. Potential EIDs due to wildlife in Gabon are thereby plentiful and need to be inventoried.

\section{Known emerging viral diseases in Gabon}

At least 51 endemic or potential endemic viral infectious diseases have been reported in Gabon ${ }^{28}$ (Table 1). Among them, 22 are of zoonotic origin and involve 12 families of viruses. The most represented are Flaviviridae (dengue virus, yellow fever virus (YFV), zika fever virus), Poxviridae (monkeypox virus (MPXV)), Filoviridae (ebola and marburg Viruses), Arenaviridae (lassa fever virus), Bunyaviridae (RVFV) and Togaviridae (chikungunya virus).

During the past two decades, several outbreaks of these zoonotic viral diseases have been reported in Gabon. All of them had a major impact on the public health:

- Zaïre ebola virus (ZEBOV): in Gabon, ZEBOV outbreaks occurred in 1994, 1996, 1997 and 2001; ${ }^{29}$ primary human cases were generally contaminated by direct contact with 


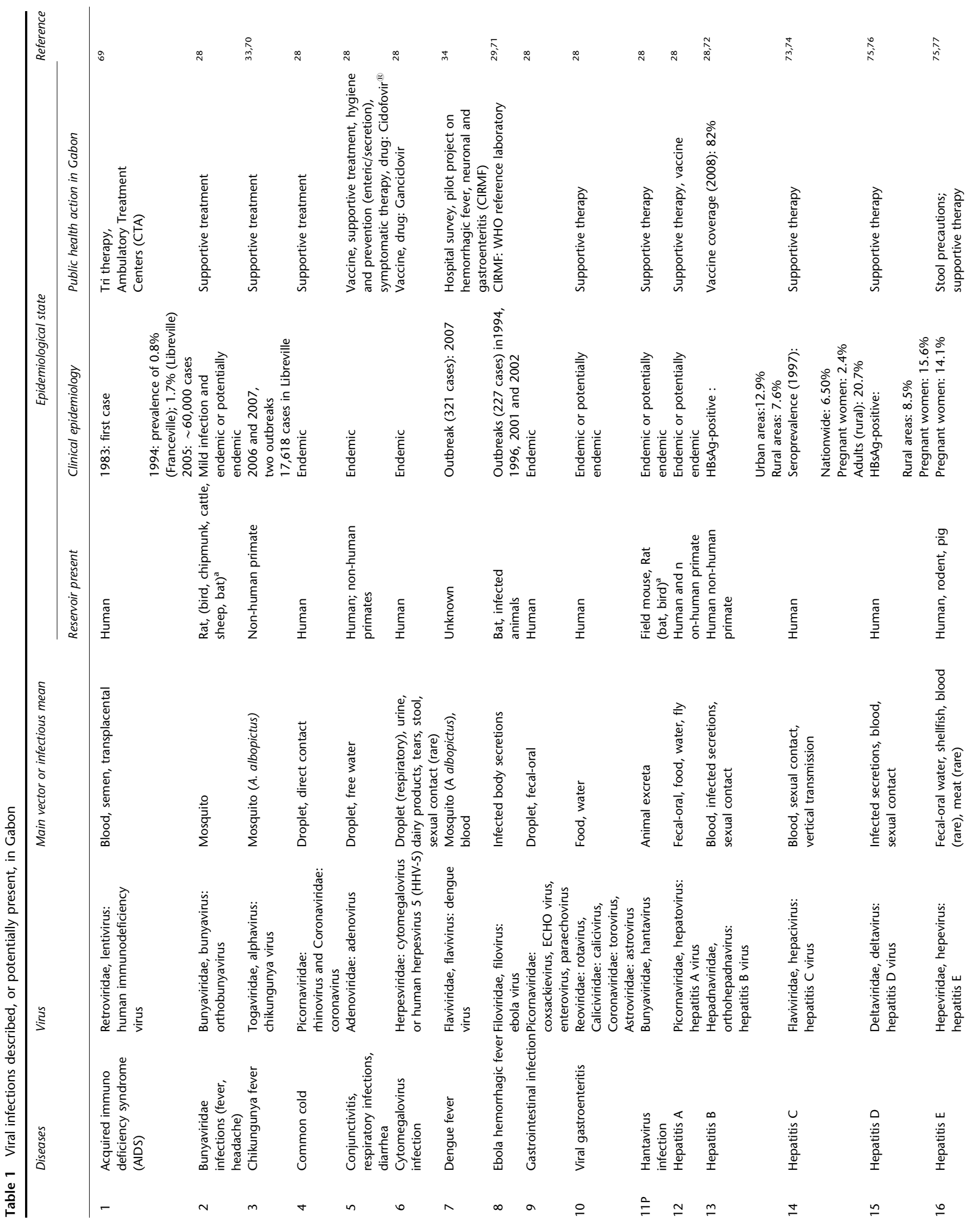




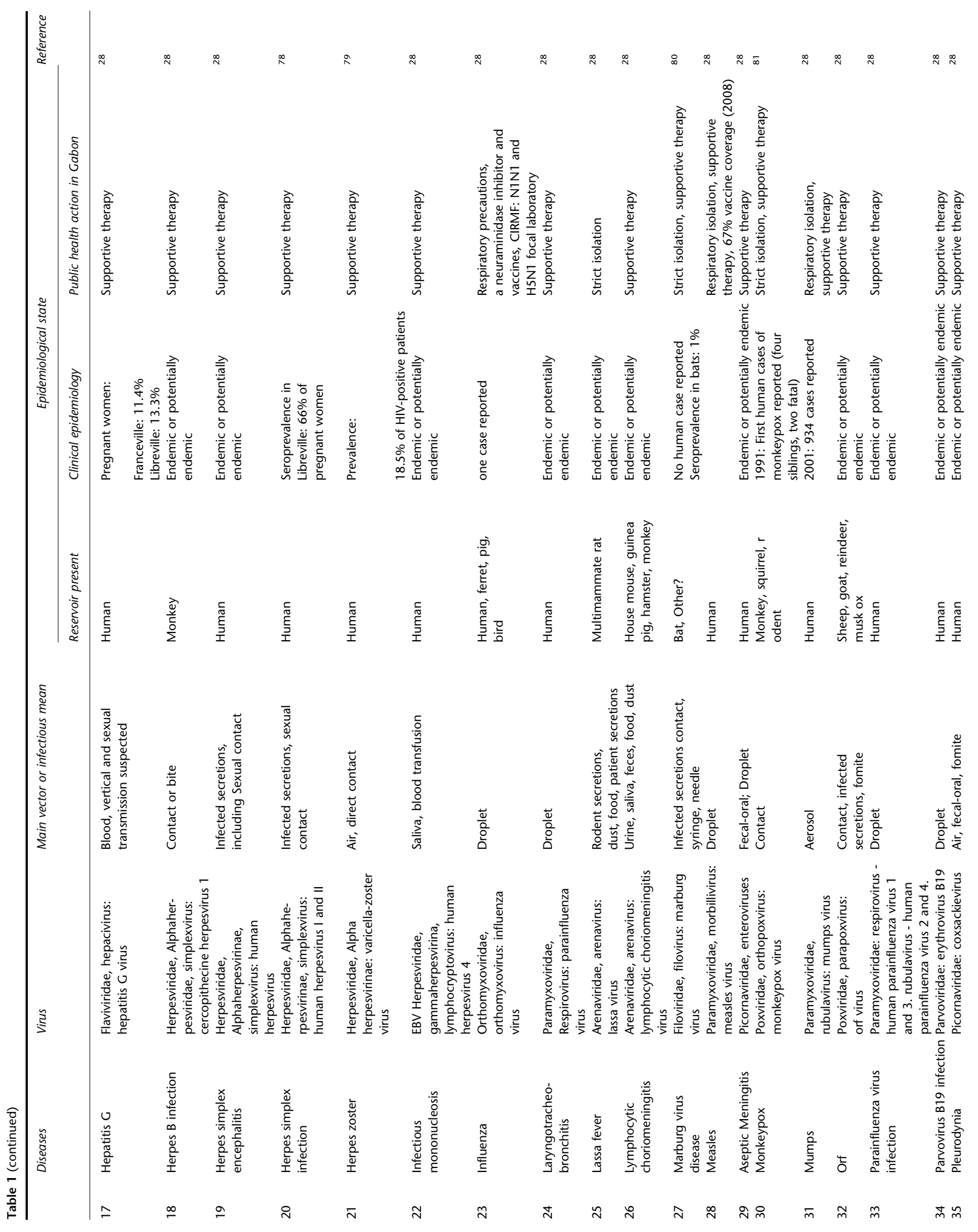



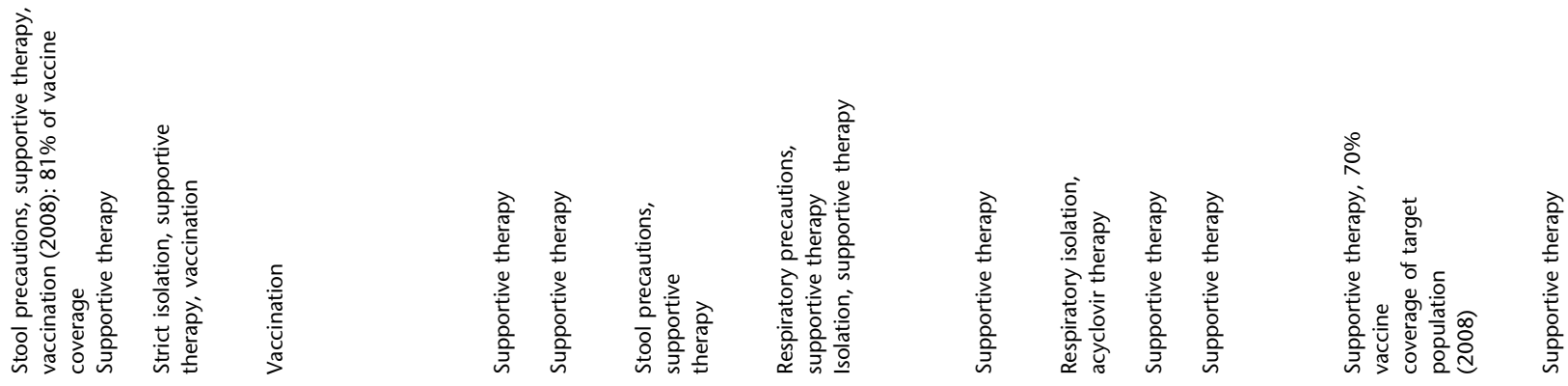

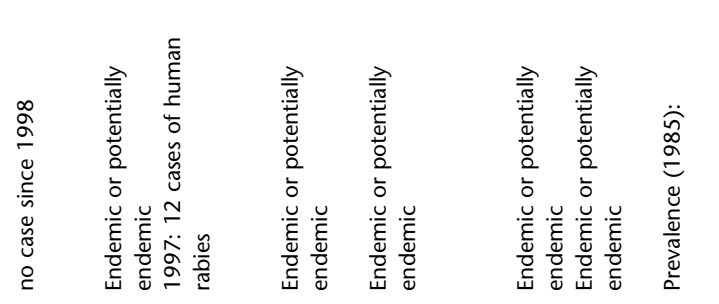

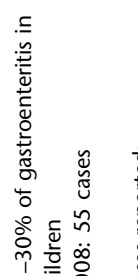

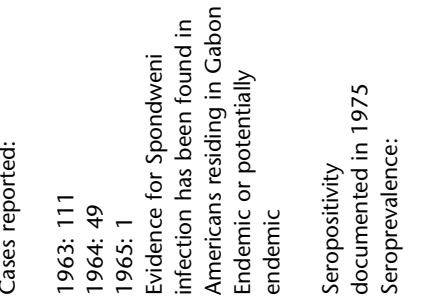

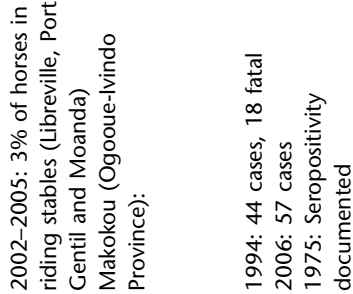

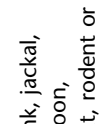

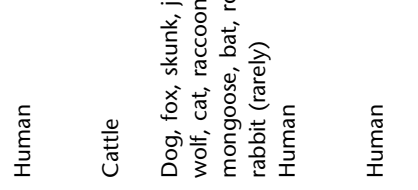

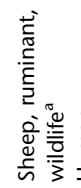

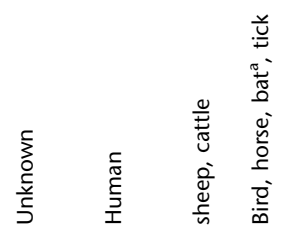

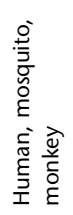

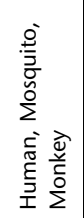

产

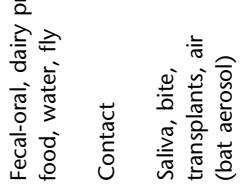

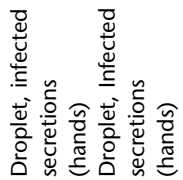

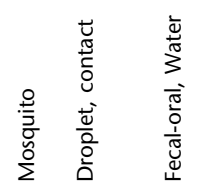

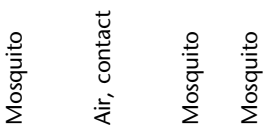

$\stackrel{\circ}{\bar{z}}$
$\frac{\bar{g}}{2}$

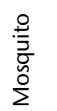

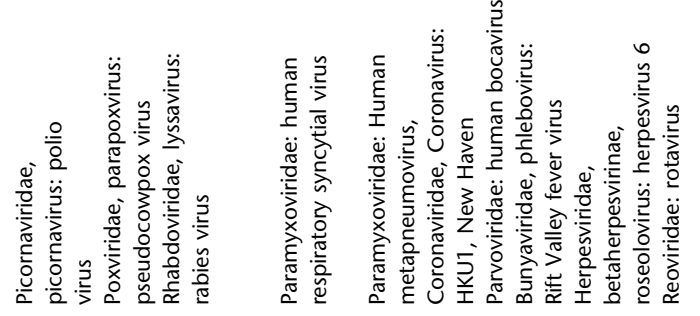

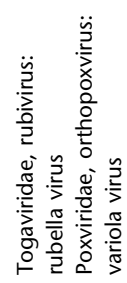

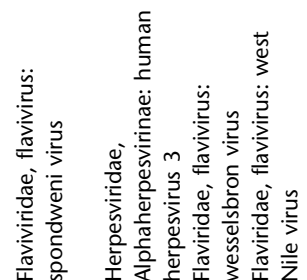

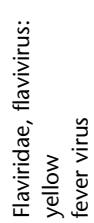

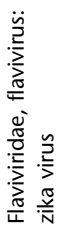

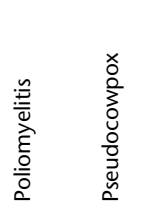

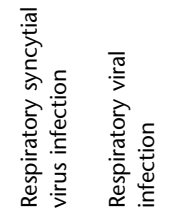

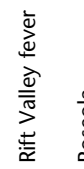

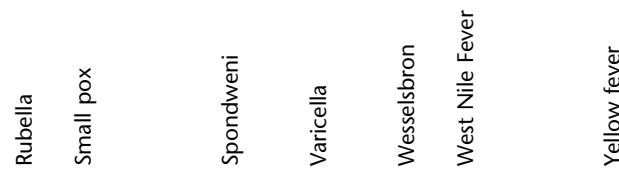

$\stackrel{m}{m} \stackrel{\infty}{m}$

m $q$

₹ $₹ \mathcal{q}$

๖

\&

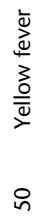


dead wild animals, such as great apes (chimpanzee and gorilla), which are highly susceptible to the disease, and therefore human outbreaks were often preceded by an animal epizootic (great apes). Since the first recorded outbreak in 1976, 20 human epidemics have occurred in Central Africa ${ }^{29,30}$ with three recent outbreaks in RDC and Uganda in 2007 and 2008.

- Chikungunya virus (CHIKV): CHIKV has recently dispersed to new regions of the world including Gabon where two outbreaks in 2006 and 2007 mainly hit the capital, Libreville. ${ }^{31,32}$ A total of 17,618 human cases were reported. ${ }^{33}$ The outbreaks appeared concomitantly with the spread in peridomestic urban areas of Aedes albopictus, the mosquito known as the main vector of the most recent epidemics of CHIKV. ${ }^{34} \mathrm{CHIKV}$ disease had reemerged in $2001-2003^{35}$ in the Indian Ocean after a 20-year gap with a new epidemiological pattern including $A$. albopictus as the main vector of epidemics and an adapted virus strain presenting an original mutation suspected to be responsible for an increase of pathogenicity. ${ }^{36}$

- Dengue virus (DENV): a DENV outbreak occurred in Gabon simultaneously with the CHIKV outbreak in 2007, ${ }^{33}$ and concurrent infections of DENV and CHIKV have been reported in towns affected by the two outbreaks. ${ }^{34}$ Dengue fever and the severe form of the disease, dengue hemorrhagic fever (DHF), are caused by the world's most prevalent mosquito-borne virus. ${ }^{37} \mathrm{DENV}$ is carried by Aedes aegypti mosquito, which is strongly affected by ecological and human drivers, but also influenced by climate (temperature, humidity and solar radiation). ${ }^{37}$ Although DENV was known to circulate among mosquitoes within limited areas in West Africa and East Africa, dengue fever first emerged among the African population during the epidemic of Nigeria in $1964-1968,{ }^{38}$ then in Senegal in $1980^{39}$ and Burkina Faso and Kenya in 1982. ${ }^{40,41}$ Since then epidemic manifestations were recorded in East Africa (Mozambique, Sudan, Djibouti, Somalia, Eritrea), in Senegal and more recently in Gabon. ${ }^{34,42}$ It seems that dengue fever is on the edge of emergence in Africa with the potential appearance of the devastating DHF that is yet to be observed on the continent.

- Yellow Fever Virus (YFV): Gabon is officially designated as an infected country. A YFV outbreak occurred in 1994 in Ogooue-Ivindo Province, North East of Gabon with 44 cases reported. ${ }^{43}$ More recently, in 2009, Cameroon reported a laboratory-confirmed case of yellow fever (YF). ${ }^{44}$ YF has become an important public health issue because of its case-fatality rate of $50 \%$ and the estimated 200,000 cases and 30,000 deaths that occur each year worldwide. Also, despite the efficiency of the YF vaccine and its inclusion in the national vaccination program, human populations situated in remote areas have a limited access to the public health system.

Potential emerging zoonotic diseases in Gabon

Based on serological evidence, several pathogens identified among wild or domestic animals, are suspected to infect the human populations of Gabon and therefore represent a potential threat to public health. Among them are the follows:

- Foamy virus: simian foamy virus (SFV), a retrovirus in the Spumaretrovirinae subfamily, is widely prevalent in wildcaught and captive-born non human primates. ${ }^{45,46}$ Contamination between non-human primates and humans can occur via contact with infectious body fluids, through biting, ${ }^{45,47}$ or when manipulating fresh bush-meat. ${ }^{48,49}$ However, the potential for SFV to become a human disease and to spread among human populations after crossspecies transmission is not yet fully understood. ${ }^{50}$

- Human monkeypox: Human monkeypox, caused by the MPXV, a member of the genus Orthopoxvirus, is clinically almost identical to ordinary smallpox. ${ }^{51}$ Humans become infected through direct contact with infected wild animals. It seems that monkeys are also incidental hosts as the reservoir species of MPXV remain unknown (most likely one or several rodents living in secondary forests of Central Africa). ${ }^{51}$ Epidemiological surveys recorded 47 cases of human monkeypox (7 lethal) in Central Africa (RDC, Gabon, Congo, CAR, Cameroun, Ivory Cost, Liberia, Sierra Leone and Nigeria $)^{52}$ with possible secondary transmission in the human population. Since 1980, the large majority of cases to be reported from the DRC mainly concern children. ${ }^{51}$ In $72 \%$ of those cases, an animal source of infection was suspected whereas secondary transmission from human source was presumed for the remaining cases. The longest documented chain of infection did not exceed four generations of person-to person transmission. There is only little probability of a large epidemic spread of MXPV. ${ }^{53}$

- Rift valley fever virus (RVFV): Rift Valley fever is an African disease that affects both livestock and humans. RVF outbreaks are associated with persistent heavy rainfall, sustained flooding and appearance of large numbers of mosquitoes, the main vector. Localized heavy rainfall is seldom sufficient to create conditions for an outbreak; ${ }^{54,55}$ Rift Valley fever is a good example of a disease that is well coupled with climatic anomalies; and Gabon is one of the African countries known to have some evidence of RVFV circulation as antibodies of the disease has been found in humans and livestock. ${ }^{55}$

\section{Impact of a changing environment}

Climatic variations and extreme weather events have a profound impact on infectious diseases: ${ }^{56}$ for example, the emergence of vector-borne diseases is highly sensitive to changes in environmental conditions (rainfall, temperature, severe weather events). ${ }^{56}$ Indeed arthropod vectors (that is mosquito, ticks...) are devoid of thermostatic mechanisms, hence reproduction and survival rates are strongly affected by fluctuations in temperature. ${ }^{37} \mathrm{~A}$ rise in arthropodborne EID events due to climate anomalies has been observed during the 1990 's. $^{3}$ Average global temperatures 
are predicted to be $1.0-3.5^{\circ} \mathrm{C}$ by $2100 .^{57}$ Further epidemic events of vector-borne diseases due to climate change are, therefore, to be expected.

Concerning other zoonotic infectious diseases like ebola, marburg or RVF, too little information is available concerning their ecology to be able to assess the impact of climate changes on the potential emergence or re-emergence of these diseases. However some preliminary reports show a strong association between wet environment (rainfall and hydrographic conditions directly dependent on climate and climate change) and the recent reemergence of ebola fever in Gabon and RDC. ${ }^{58}$ Also El Niño/Southern oscillation (ENSO) is the strongest naturally occurring source of climate variability around the globe, ${ }^{59}$ and more than $75 \%$ of RVF outbreaks between 1950 and 1988 occurred during warm ENSO event periods. ${ }^{54}$ Moreover, RVF epidemics between 1950 and 1998 have coincided with unusually high rainfall in East Africa. ${ }^{60}$

\section{Epidemic prevention and control}

Existing structures in Gabon (data cited below was updated in 2007, ministry of public health, Gabon ${ }^{61}$ )

Gabon has one of the highest expenditure on health per capita in Africa. In 2006, Gabon's total health care expenses were comparable to eastern European countries and most southern American countries: ${ }^{62}$ between 300 and 1000 US\$ per capita.

The Gabonese Public Health System comprises five different health sectors: (1) the civilian public sector under the public Health and Hygiene Ministry, (2) the public military sector under the Ministry of Defense, (3) the National Health Social Security Funding and private insurances, (4) the private health sector and (5) the traditional health sector. ${ }^{61}$

This public Health system geographically covers most of the country allowing a good access to sanitary information and efficient monitoring of emerging diseases. However, access to treatment and prevention is much better in urban areas where medical structures are more developed, more organized with higher level of technicality and material ${ }^{61}$ while the population is equally distributed between urban and rural areas (Table 2). A total of $60 \%$ of human and equipment resources from the Gabonese government are allocated to the main cities. In fact, all hospitals and clinics are found in Libreville, Port Gentil, Franceville and the surrounding areas, whereas in the distant rural areas, the numerous small health structures like Mother and Child Health Centers, Health Medical Centers, and Primary Care Health Center (Table 2) are often old with limited basic equipment and drugs. ${ }^{61}$ Also the medical staff is more concentrated in urban areas (Table 3). Indeed, more than $70 \%$ of the doctors and midwives are assigned to urban areas as well as $58 \%$ of the druggists. Only public nurses are equally distributed between rural and urban areas.

To fight against diseases, Gabon has developed 17 national health control programs. These programs monitor diseases such as HIV and sexually transmitted diseases, malaria, tuberculosis and also include a wide vaccination program, which covers $100 \%$ of the Gabonese territory. Despite the existence of 10 epidemiological stations distributed around the country in both rural and urban areas (Table 2) that act as surveillance outposts, there is no other national health program to combat the more neglected EIDs.

In addition to public health Ministry activities, there are the following in Gabon:

- The CENAREST (National Center for Scientific and Technologic Research) that evaluates and carries out research in Gabon, contributes to the application and promotion of research results and supports research training.

- The CIRMF (International Medical Research Centre of Franceville), a Gabonese world-renowned scientific research center, inaugurated in 1979, the CIRMF had for an initial focus to study the reasons for infertility in Central African populations. By the mid 1980s, CIRMF broadened its research to focus also on tropical diseases including HIV, trypanosomiasis and malaria. More recently CIRMF concentrated also on EIDs including the deadly ebola and marburg viruses, CHIKV and DENV. ${ }^{63}$ Its central position in Africa and its world-renowned researchers ensure that CIRMF benefits from support and collaboration from several international institutions including the WHO (World Health Organization), the CIRAD (Centre de Coopération Internationale en Recherche Agronomique pour le développement), the IRD (Institut de Recherche pour le Développement), the Pasteur Institute, the CDC (Centers for Disease Control and Prevention), and several overseas universities from Europe, North America, South America and Asia.

- International NGOs (non-governmental organizations) are also involved in research on emerging diseases in Gabon. For example, the WCS (Wildlife Conservation Society) with its 'One World, One Health' Program and the Zoological Society of London and its 'Mikongo Conservation Centre' are working on great ape diseases, wildlife monitoring and the bush meat trade.

\section{Regional organizations}

In Central Africa there are few regional organizations involved in public health:

- The OCEAC (Organisation de coordination pour la lute contre les endémies en Afrique Centrale) is an organization of coordination and cooperation to fight major endemic diseases in Central Africa. Created in 1963, in Yaounde, by the determination of the health ministers of Cameroon, Congo, Gabon, CAR and Chad, it was originally known as the OCCGEAC until 1965. The Equatorial Guinea joined later the OCEAC. Its goals are to (1) coordinate public health policies and actions in Central African region, (2) participate in the training of the medical staff of member countries of the organization, 


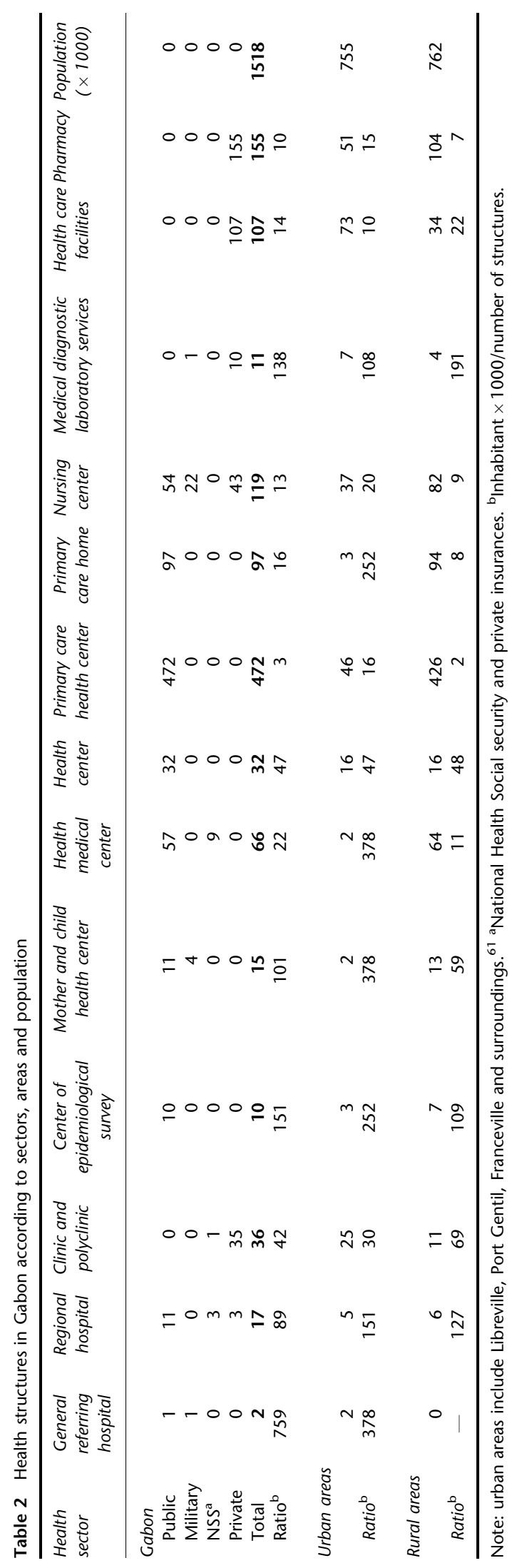

www.eht-journal.org

(3) coordinate applied research projects undertaken by national institutions, (4) implement missions of expertise in the different areas of health sciences, (5) contribute to the public health promotion in the member countries and (6) support the actions undertaken in response to health emergencies. Today OCEAC is in charge of regional health programs and projects like the Sub Regional Program against HIV/AIDS, the Harmonization Program for Pharmaceutical Policy, the Regional Program to fight human African trypanosomiasis and research projects on malaria.

- The CEMAC (Communauté Économique des États d'Afrique Centrale-Economic Community of Central African States) is an economic community of the African Union for promotion of regional economic co-operation in Central Africa. Member countries include Gabon, Republic of Congo, Equatorial Guinea, CAR, Cameroon and Chad. It 'aims to achieve collective autonomy, raise the standard of living of its populations and maintain economic stability through harmonious cooperation'. It was established in 1983 and its ultimate goal is to establish a Central African Common Market. However CEMAC may have a role in the public health systems in Central Africa: in 2009, CEMAC signed a memorandum of understanding with Germany, which donated a 23 million euro grant for the prevention of HIV in Central Africa.

- The CIESPAC (Centre inter-états d'Enseignement en Santé Publique pour l'Afrique centrale) is a sub-regional public health training institution, originally located in Brazzaville. It was created to provide Central African countries with qualified health service staff and managers. It offers several courses, the most recent of which is recognized with a professional diploma in public health and targets mainly potential health district managers. ${ }^{64}$ The civil war events that occurred in Brazzaville in the late nineties provoked the transfer of the institution to Yaoundé, Cameroon.

- The CAMES (Conseil Africain et Malgache pour l'Enseignement Supérieur-African and Malagasy Council for Higher Education) exists to (1) promote and encourage the understanding and the solidarity between member States, (2) establish a permanent cultural and scientific cooperation between member states, (3) collect and diffuse all academic and research documents, (4) prepare agreement drafts between states concerned by Higher Education and Research and contribute to their implementation and finally (5) develop and promote dialogues to coordinate the higher education system and research so as to standardize programs and recruitment levels. This means that Gabonese university lecturers and researchers (in particular health researcher) are assessed by CAMES before obtaining a promotion.

\section{International organizations}

Gabon is part of the Global Outbreak Alert and Response Network (GOARN), which contributes towards global health security by, ${ }^{65}$ (1) fighting the international spread of 
Table 3 Public health medical staff in Gabon according to specific environmental areas

\begin{tabular}{lrrr}
\hline & Urban areas $^{\mathrm{a}}$ & ${\text { Rural } \text { areas }^{\mathrm{a}}}$ & Total \\
\hline Medical doctor & $299(75)$ & $100(25)$ & 399 \\
Pharmacist & $38(58)$ & $27(42)$ & 65 \\
Nurse & $2432(54)$ & $2036(46)$ & 4469 \\
Midwife & $369(71)$ & $146(29)$ & 515 \\
\hline
\end{tabular}

Note: urban areas include Libreville, Port Gentil, Franceville and surroundings. ${ }^{61}$ a Number (percentage).

outbreaks, (2) ensuring that appropriate technical assistance rapidly reaches affected countries, and (3) contributing to long-term epidemic preparedness and capacity building. On top of that, the CDC, in conjunction with the WHO, has developed practical, hospital-based guidelines, titled Infection Control for Viral Haemorrhagic Fevers in the African Health Care Setting. This manual helps health-care facilities to recognize cases and prevent further hospital-based disease transmission using locally available materials and only little financial resources (http://www.cdc.gov/ncidod/dvrd/spb/ mnpages/dispages/vhf.htm). Moreover, in November 2007, a meeting to discuss the integrated control of neglected zoonotic diseases in Africa was held in Nairobi, Kenya. It was organized by the WHO and jointly supported by the European Commission, the ILRI (International Livestock Research Institute), the Danish Centre for Health Research and Development (formerly the Danish Bilharziasis Laboratory), the FAO (United Nations Food and Agriculture Organization), the OIE (World Organisation for Animal Health) and the African Union. ${ }^{66}$

\section{Conclusion}

Infectious diseases, including zoonoses, remain the major and increasing health threat in most developing countries. ${ }^{1,3,6,67}$ Even if in industrialized countries, cardiovascular diseases and cancers are considered to be the main causes of illness and death, special attention still needs to be paid to zoonotic EID. ${ }^{67}$ This statement is now well described by the 'one health-one medicine-one world' concept which is a worldwide strategy for expanding interdisciplinary collaboration and communications in all aspects of health care for humans and animals and the interaction with environmental factors. Also, viral hemorrhagic fevers, because of their high infectiousity and the dramatic outcome, have attracted the attention of the medical world and the public in Africa and around the world to this particular category of EID. ${ }^{68}$

However, global effort in EID surveillance and investigation is inadequately allocated. Indeed, the majority of scientific resources focus on places from where the next important emerging pathogen is least likely to originate. ${ }^{3}$ Jones et al. advocated for the re-allocation of resources to EID hotspots in lower latitudes, such as tropical Africa because of the critical need for health monitoring and identification of new potentially zoonotic pathogens in African wildlife populations, and this to be used as a forecast measure for EIDs. $3,48,67$

Like other African countries, Gabonese resources for public health and health monitoring are unequally allocated; $60 \%$ are spent at a central level. Public health services and clinical practitioners need more resources to be able to actively educate the public about the risks of repeated contacts with wildlife or other sources potentially harmful for health. ${ }^{48}$ However, Gabon could be considered as a good model to investigate the emergence or re-emergence of zoonotic EID. On one hand, Gabonese forests are a hot spot for biodiversity (wild animals and unknown pathogens) and on the other hand there is a relatively small population (1.5 million of habitants), which is often in contact with surrounding wildlife. Also, the CIRMF, a research center advantageously located, offers high quality researchers and facilities that study pathogens and wildlife ecology. Altogether the combination of these factors should help to better understand the mechanisms of contact and transmission of new pathogens from wildlife to human, the emergence of zoonotic EID and the breaking of species barriers by the pathogens. Indeed the emergence of infectious diseases in wildlife is a continuous and ongoing process. The factors that give rise to zoonotic EID, such as ecosystem perturbations and modifications, climate changes, migrations of reservoirs species, pathogens or vectors, and intrinsic changes of pathogens may be of natural origin or due to human influences. ${ }^{17}$ To understand the underlying mechanisms that govern relationships between reservoir species, ecological factors and environmental perturbations with the emergence, transmission and dissemination of viral diseases in tropical forests, the CIRMF wishes to set up permanent surveillance of the health of the population by the establishment of (1) a network reference laboratories (WHO based reference laboratories including CIRMF, Pasteur Institute Network and other National laboratories or universities based) and (2) a Health Ecology Observatory (that is,. The CIRMF's Scientific Station in la Lopé National Park). Such measures will compile data from the public health system with the monitoring of the emergence of new pathogens. The collected information would favor better outbreak risk appraisal in the Gabonese human population as well as for the entire Congo basin region.

\section{Acknowledgements}

Centre International de Recherches Médicales de Franceville is supported by the Government of Gabon, Total-Fina-Elf Gabon, and the Ministère de la Coopération Française.

\section{References}

1 Morens DM, Folkers GK, Fauci AS. The challenge of emerging and re-emerging infectious diseases. Nature 2004;430:242-9.

2 Ludwig B, Kraus FB, Allwinn R, Doerr HW, Preiser W. Viral Zoonoses - a threat under control? Intervirology 2003;46: 71-8. 
3 Jones KE, Patel NG, Levy MA, Storeygard A, Balk D, Gittleman JL, et al. Global trends in emerging infectious diseases. Nature 2008;451:990-3.

4 Bengis RG, Leighton FA, Fischer JR, Artois M, Mörner T, Tate CM. The role of wildlife in emerging and re-emerging zoonoses. Rev Sci Tech Off Int Epiz 2004;23:497-511.

5 Woolhouse ME. Population biology of emerging and re-emerging pathogens. Trends Microbiol 2002;10:S3-7.

6 Weiss RA, McMichael AJ. Social and environmental risk factors in the emergence of infectious diseases. Nat Med 2004;10:S70-S6.

7 Meslin FX, Stöhr K, Heymann D. Public health implications of emerging zoonoses. In: Seimenis AM (ed) Special issue on emerging and re-emerging zoonoses. WHO: Geneva, 2001; 2-6.

8 Seimenis AM. Special issue on emerging and re-emerging zoonoses. Inf Circular 2001; 53:16.

9 Myers N. Tropical forests and their species. In: Wilson EO (ed) Biodiversity. National Academy: Washington, 1988; 28-35.

10 Wilson EO. The current state of Biodiversity. In: Wilson EO (ed) Biodiversity. National Academy: Washington, 1988; 3-18.

11 Guernier V, Hochberg ME, Guégan J-F. Ecology drives the worldwide distribution of human diseases. PLoS Biol 2004;2:e141.

12 Minnemeyer S. An Analysis of Access into Central Africa's Rainforests. World Resources Institute: Washington DC, 2002.

13 Woolhouse MEJ, Gowtage-Sequeria S. Host range and emerging and reemerging pathogens. Emerg Infect Dis 2005;11:1842-7.

14 Brown C. Emerging zoonoses and pathogens of public health significance-an overview. Revue Scientifique et Technique-Office International des Epizooties 2004;23:435-42.

15 Feldmann H, Czub M, Jones S, Dick D, Garbutt M, Grolla A, et al. Emerging and re-emerging infectious diseases. Med microbiol immunol 2002;191:63-74.

16 Dobson A, Foufopoulos J. Emerging infectious pathogens of wildlife. Philos Trans R Soc B Biol Sci 2000;356:1001-12.

17 Williams ES, Yuill T, Artois M, Fischer J, Haigh SA. Emerging infectious diseases in wildlife. Revue Scientifique et Technique-Office International des Epizooties 2002;21:139-58.

18 Daszak P, Cunningham AA, Hyatt AD. Emerging infectious diseases of wildlife - threats to biodiversity and human health. Science 2000;287:443-9.

19 Bermejo M, Rodriguez-Teijeiro JD, Illera G, Barroso A, Vila C, Walsh PD. Ebola outbreak killed 5000 Gorillas. Science 2006;314:1564.

20 Karesh W, Reed P. Ebola and great apes in Central Africa: current status and future needs. Bull Soc Pathol Exot 2005;98:237-8.

21 Leroy EM, Rouquet P, Formenty P, Souquiere S, Kilbourne A, Froment JM, et al. Multiple ebola virus transmission events and rapid decline of central african wildlife. Science 2004;303:387-90.

22 Walsh PD, Abernethy KA, Bermejo M, Beyers R, De Wachter P, Akou ME, et al. Catastrophic ape decline in western equatorial Africa. Nature 2003;422:611-14

23 Doumenge C, Yuste JEG, Gartlan S, Langrand O, Ndinga A. Conservation de la Biodiversité forestière en Afrique centrale Atlantique : Le réseau d'aires protégées est-il adéquat ? Bois et Forêts des Tropiques 2001;268:5-28.

24 WHO. Immunization surveillance, assessment and monitoring 2009. (http://www.who.int/immunization_monitoring/en/globalsummary/countryprofileresult.cfm).

25 FAO. State of the world's forests 2001. FAO: Rome, 2001.

26 Laurance WF, Croes BM, Guissouegou N, Buij R, Dethier M, Alonso A. Impacts of roads, hunting, and habitat alteration on nocturnal mammals in african rainforests. Conserv Biol 2008;22:721-32.

27 Binot A, Cornelis D. Synthèse bibliographique du secteur 'Viande de Brousse' au Gabon. CIRAD: Montpellier, 2004. p 106.

28 GIDEON. GIDEON The world's premier global infectious diseases database, 2009. ( http://web.gideononline.com/web/epidemiology/).

29 Pourrut X, Kumulungui B, Wittmann T, Moussavou G, Delicat A, Yaba $\mathrm{P}$, et al. The natural history of Ebola virus in Africa. Microbes Infect 2005; 7:1005-14.
30 Towner JS, Sealy TK, Khristova ML, Albariño CG, Conlan S, Reeder SA, et al. Newly discovered ebola virus associated with hemorrhagic fever outbreak in Uganda. PLoS Pathog 2008;4:e1000212.

31 de Lamballerie X, Leroy E, Charrel R, Ttsetsarkin K, Higgs S, Gould E. Chikungunya virus adapts to tiger mosquito via evolutionary convergence: a sign of things to come? Virol J 2008;5:33.

32 Pagès F, Peyrefitte $\mathrm{CN}$, Mve MT, Jarjaval F, Brisse S, Iteman I, et al. Aedes albopictus mosquito: the main vector of the 2007 chikungunya outbreak in Gabon. PLOS ONE 2009;4:e4691.

33 Peyrefitte CN, Bessaud M, Pastorino BAM, Gravier P, Plumet S, Merle OL, et al. Circulation of chikungunya virus in Gabon, 2006-2007. J Med Virol 2008;80:430-3.

34 Leroy EM, Nkoghe D, Ollomo B, Nze-Nkogue C, Becquart P, Grard G, et al. Concurrent chikungunya and dengue virus infections during simultaneous outbreaks, Gabon, 2007. Emerg Infect Dis 2009;15:591.

35 Laras K, Sukri NC, Larasati RP, Bangs MJ, Kosim R, Djauzi, et al. Tracking the re-emergence of epidemic chikungunya virus in Indonesia. Trans R Soc Trop Med Hyg 2005;99:128-41.

36 Schuffenecker I, Iteman I, Michault A, Murri S, Frangeul L, Vaney $\mathrm{MC}$, et al. Genome microevolution of chikungunya viruses causing the Indian Ocean outbreak. PLoS Med 2006;3:e263.

37 Kovats RS, Campbell-Lendrum D, McMichael AJ, Woodward A, Cox JSH. Early effects of climate change: do they include changes in vector-borne disease? Philos Transact of the R Soc B: Biol Sci 2001;356:1057-68.

38 Carey DE, Causey OR, Reddy S, Cooke AR. Dengue viruses from febrile patients in Nigeria, 1964-68. Lancet 1971;1: $105-6$.

39 Saluzzo JF, Cornet M, Castagnet P, Rey C, Digoutte JP. Isolation of dengue 2 and dengue 4 viruses from patients in Senegal. Trans $R$ Soc Trop Med Hyg 1986;80:5.

40 Gonzalez JP, Du Saussay C, Gautun JC, McCormick JB, Mouchet J. The dengue in Burkina Faso (Upper Volta). Seasonal epidemics in the city of Ouagadougou. Bulletin de la Société de pathologie exotique 1985;78:7-14.

41 Johnson BK, Ocheng D, Gichogo A, Okiro M, Libondo D, Kinyanjui $\mathrm{P}$, et al. Epidemic dengue fever caused by dengue type 2 virus in Kenya: preliminary results of human virological and serological studies. East Afr Med J 1982;59:781-4.

42 Sang RC. Secondary Dengue in Africa. Nairobi: Kenya, 2007; 4.

43 WHO. Yellow fever. Wkly Epidemiol Rec 1995;70:163-4.

44 WHO. Yellow fever in Cameroon. Dis Outbreak News 2009. (http://www.who.int/csr/don/2009_10_01/en/index.html).

45 Murray SM, Linial ML. Foamy virus infection in primates. J Med Primatol 2006;35:225-35.

46 Switzer WilliamÂA M, Garcia Albert Â D, Yang C, Wright A, Kalish MarciaÂ L, Folks Thomas Â M, et al. Coinfection with HIV-1 and Simian Foamy Virus in West Central Africans. J Infect Dis 2008;197:1389-93.

47 Calattini S, Nerrienet E, Mauclere P, Georges-Courbot MC, Saib A, Gessain A. Detection and molecular characterization of foamy viruses in Central African chimpanzees of the Pan troglodytes troglodytes and Pan troglodytes vellerosus subspecies. I Med Primatol 2006;35:59-66.

48 Chomel BB, Belotto A, Meslin FX. Wildlife, exotic pets, and emerging zoonoses. Emerg Infect Dis 2007;13:6.

49 Wolfe ND, Switzer WM, Carr JK, Bhullar VB, Shanmugam V, Tamoufe $\mathrm{U}$, et al. Naturally acquired simian retrovirus infections in central African hunters. Lancet 2004;361:932-7.

50 Switzer WM, Bhullar VB, Shanmugam V, Cong ME, Parekh B, Lerche NW, et al. Frequent simian foamy virus infection in persons occupationally exposed to nonhuman primates. $J$ Virol 2004;78:2780-9.

51 Nalca A, Rimoin AnneÂ W, Bavari S, Whitehouse Chriŝ̂ A. Reemergence of monkeypox: prevalence, diagnostics, and countermeasures. Clin Infect Dis 2005;41:1765-71. 
52 Breman JG, Kalisa R, Steniowski MV, Zanotto E, Gromyko AL, Arita I. Human monkeypox, 1970-1979. Bull World Health Organ 1980;58:165-82.

53 Jezek Z, Arita I, Mutombo M, Dunn C, Nakano JH, Szczeniowski M. Four generations of problable person-to-person transmission of human monkeypox. Am J Epidemiol 1986;123:1004-12.

54 Anyamba A, Linthicum KJ, Tucker CJ. Climate-disease connections: Rift Valley fever in Kenya. Cadernos de Saúde Pública 2001;17:133-40.

55 Gerdes GH. Rift valley fever. Revue Scientifique et Technique-Office Int des Epizooties 2004;23:613-23.

56 Patz JA, Campbell-Lendrum D, Holloway T, Foley JA. Impact of regional climate change on human health. Nature 2005;438:310-17.

57 Watson RT, Zinyowera MC, Moss RH, Dokken DJ. Climate change 1995: impacts, adaptations and mitigation of climate change: scientific-technical analyses. Cambridge University Press. GB: Cambridge, 1996.

58 Moussavou G. Apport de la télédétection et des systèmes d'information géographique dans l'étude des conditions environnementales liées à l'apparition des épidémies de fièvre Ebola au Gabon et au Congo. Université de Marne la Vallée: Paris, France, 2007.

59 Ropelewski CF, Halpert MS. Global and regional scale precipitation patterns associated with the El Niño/Southern Oscillation. Monthly Weather Rev 1987;115:1606-26.

60 Linthicum KJ, Anyamba A, Tucker CJ, Kelley PW, Myers MF, Peters CJ. Climate and satellite indicators to forecast Rift Valley fever epidemics in Kenya. Science 1999;285:397-400.

61 CosP Secondary Cellule d'Observation de la Santé Publique. Ministère de la Santé Publique et de l'Hygiène Publique. Carte sanitaire du Gabon. Libreville: Gabon, 2009; 123.

62 WHO. WHO total expenditure on health per capita, 2006 (in US \$). National Health Accounts series. http://www.who.int/nha/use/THE_ pc_US\$_2006.png.

63 Butler D. Gabon centre refocuses on emerging diseases. Nat News 455:1156-7.

64 Vigouroux AL. A description of a community-oriented cum pbl post graduate training course for health districts managers in Central Africa. Educ Health 2002;15:158-65.

65 Formenty P, Roth C, Gonzalez-Martin F, Grein T, Ryan M, Drury P, et al. Les pathogènes émergents, la veille internationale et le Règlement sanitaire international (2005). Médecine et Maladies Infectieuses 2006;36:9-15.

66 WHO. Integrated control of neglected zoonotic diseases in Africa. Wkly Epidemiol Records 2009;17:147-8.

67 Meslin F-X. Global Aspects of emerging and potential zoonoses: a WHO perspective. Emerg Infect Dis 1997;3:223-8.

68 Crowcroft NS, Morgan D, Brown D. Viral haemorrhagic fevers in Europe-effective control requires a co-ordinated response. Euro Surveill 2002;7:31-2.

69 Bertherat E, Georges-Courbot MC, Nabias R, Georges AJ, Renaut A. Seroprevalence of four sexually transmitted diseases in a semi-urban population of Gabon. Int J STD AIDS 1998;9:31-6.

70 Vazeille M, Moutailler S, Pages F, Jarjaval F, Failloux A-B. Introduction of 'Aedes albopictus' in Gabon: what consequences for dengue and chikungunya transmission? Trop Med Int Health 2008;13:1176-9.
71 Gonzalez JP, Pourrut X, Leroy E. Ebolavirus ans other filovirus. In: Childs JE, Mackenzie JS, Richt JA (eds) Wildlife and Emerging Zoonotic Diseases: The Biology, Circumstances and Consequences of Cross-species Transmission. Springer: Berlin, 2007; 363-88.

72 Makuwa M, Mintsa-Ndong A, Souquiere S, Nkoghe D, Leroy EM Kazanji M. Prevalence and molecular diversity of hepatitis B virus and hepatitis delta virus in urban and rural populations in northern Gabon in central Africa. J Clin Microbiol 2009;47: 2265-8.

73 Ndong-Atome GR, Makuwa M, Njouom R, Branger M, BrunVezinet F, Mahe A, et al. Hepatitis $C$ virus prevalence and genetic diversity among pregnant women in Gabon, central Africa. BMC Infect Dis 2008;8:82.

74 Ndong-Atome GR, Makuwa M, Ouwe-Missi-Oukem-Boyer O Pybus OG, Branger M, Le Hello S, et al. High prevalence of hepatitis $C$ virus infection and predominance of genotype 4 in rural Gabon. I Med Virol 2008;80:1581-7.

75 Makuwa M, Caron M, Souquiere S, Malonga-Mouelet G, Mahe A, Kazanji M. Prevalence and genetic diversity of hepatitis $B$ and delta viruses in pregnant women in Gabon: molecular evidence that hepatitis delta virus clade 8 originates from and is endemic in central Africa. J Clin Microbiol 2008;46:754-6.

76 Richard-Lenoble D, Traore O, Kombila M, Roingeard P Dubois F, Goudeau A. Hepatitis B, C, D, and E markers in rural equatorial African villages (Gabon). Am J Trop Med Hyg 1995;53: 338-41.

77 Caron M, Kazanji M. Hepatitis E virus is highly prevalent among pregnant women in Gabon, central Africa, with different patterns between rural and urban areas. Virol J 2008;5:158.

78 Ozouaki F, Ndjoyi-Mbiguino A, Legoff J, Onas IN, Kendjo E, Si-Mohamed A, et al. Genital shedding of herpes simplex virus type 2 in childbearing-aged and pregnant women living in Gabon. Int J STD AIDS 2006;17:124-7.

79 Okome-Nkoumou M, Mbounja-Loclo ME, Kombila M. Spectrum of opportunistic infections in subjects infected with HIV at Libreville, Gabon. Sante 2000;10:329-37.

80 Pourrut X, Souris M, Towner J, Rollin P, Nichol S, Gonzalez J-P, et al. Large serological survey showing cocirculation of ebola and marburg viruses in Gabonese bat populations, and a high seroprevalence of both viruses in Rousettus aegyptiacus. BMC Infect Dis 2009;9:159.

81 WHO. Monkeypox, 1991. Wkly Epidemiol Records 1992;67:101-2.

82 Gendrel D, Sitbon M, Richard-Lenoble D, Galliot A, Kombila M, Ivanoff $\mathrm{B}$, et al. Etiology of acute infantile gastroenteritis in Gabon. Bull Soc Pathol Exot Filiales 1985;78:290-5.

83 Wolfe MS, Calisher CH, McGuire K. Spondweni virus infection in a foreign resident of Upper Volta. Lancet 1982;2:1306-8.

84 Jan C, Languillat G, Renaudet J, Robin Y. A serological survey of arboviruses in Gabon. Bull Soc Pathol Exot Filiales 1978;71:140-6.

85 Cabre O, Grandadam M, Marié J-L, Gravier P, Prangé A, Santinelli $\mathrm{Y}$, et al. West Nile virus in horses, sub-Saharan Africa. Emerg Infect Dis 2006;12:1958-60.

86 Saluzzo JF, Ivanoff B, Languillat G, Georges AJ. Serological survey for arbovirus antibodies in the human and simian populations of the South-East of Gabon (author's transl). Bull Soc Pathol Exot Filiales 1982;75:262-6. 